(Rumia)

\title{
WYKROCZENIA NA TLE SEKSUALNYM W LISTACH ŚW. HIERONIMA
}

Hieronim, żyjący na przełomie IV i V wieku, w swej spuściźnie pisarskiej nie pozostawił żadnego osobnego traktatu, który ukazywałby pełny katalog wykroczeń na tle seksualnym. Dostrzegał on jednakże fakt, że życie ludzkie w niektórych dziedzinach przekracza pewne normy, a kiedy w ten sposób ulega zranieniu, Objawienie chrześcijańskie daje na to podstawową, oryginalną, głęboko ludzką i duchową odpowiedź1. Ukazując przy okazji omawiania innych tematów, również pewne wykroczenia na tle seksualnym, Hieronim chce pokazać, że są one wynikiem wcześniej doznanych zranień, niekoniecznie o tym samym zabarwieniu. W swoich listach wskazuje na kilka tego rodzaju wykroczeń, jak: cudzołóstwo, bigamię, prostytucję, homoseksualizm, pedofilię, kazirodztwo, transseksualizm, fetyszyzm, gwałt. Niektóre wykroczenia zdarzały sie również w środowisku osób duchownych. One to pozwalają na stwierdzenie, że tego typu problemy w pierwotnym Kościele były bardziej złożone - niż obecnie - ze względu na niewystarczający ówczesny aparat pojęciowy, jak i niewystarczającą znajomość natury ludzkiej, dlatego nie należy wyciągać zbyt pochopnych wniosków i nieuzasadnionych uogólnień w tych kwestiach.

1. Cudzołóstwo. Na pierwszy plan wysuwa się cudzołóstwo. Ogólna charakterystyka tego rodzaju wykroczenia opisywana jest jako niewierność i zdrada małżeńska, a także jako niewłaściwe korzystanie z cudzej miłości małżeńskiej. Inne było jednak pojęcie cudzołóstwa (adulterium) w starożytności, zwłaszcza w prawie rzymskim: wolno urodzony mężczyzna żonaty, dopuszczał się cudzołóstwa jedynie wtedy, gdy współżył poza swym małżeństwem $\mathrm{z}$ wolno urodzoną kobietą zamężną, a mógł to bezkarnie czynić z każdą niewydaną kobietą, a nawet $\mathrm{z}$ wydaną niewolnicą, wyzwolennicą lub cudzoziemką, wydana natomiast kobieta mogła być zawsze oskarżona o cudzołóstwo, jeśli współżyła z jakimkolwiek mężczyzną oprócz swego męża; chrześcijaństwo wprowadziło w tym względzie pełną równość małżonków. Cudzołóstwo może

\footnotetext{
${ }^{1}$ Por. Hieronymus, Epistulae 24, 5.
} 
być zwykłe, gdy jedna z osób jest zamężna, i podwójne, gdy obydwie osoby są związane małżeństwem²; jest ono zatem ściśle związane z wykroczeniem przeciwko nierozerwalności i świętości małżeństwa. Hieronim pisząc o świętości małżeństwa poucza potencjalnych małżonków, że przed Bogiem oboje są równi, gdyż są stworzeni na Jego obraz i podobieństwo; są także równi wobec siebie nawzajem, ponieważ oboje są ludźmi i każde z nich ulega w takiej samej mierze słabości ludzkiej ${ }^{3}$; idąc po linii owej wzajemnej równości mężczyzny względem kobiety i kobiety względem mężczyzny oraz każdych z osobna przed Bogiem wyraża pogląd, że kobieta zamężna winna pamiętać, iż sama nie rozporządza już swoim ciałem, lecz oddaje je swemu mężowi, aby nie tyle go sobie zjednać, co raczej przez zachowanie posłuszeństwa i zgody sprawić, by owoc ich małżeństwa mógł być darem dla Chrystusa ${ }^{4}$, zaznaczając przy tym, że posłuszeństwo to polega na tym, iż nie tylko mąż zarządza ciałem żony, ale też żona ciałem męża. Nasz Ojciec Kościoła pragnie ukazać małżeństwo w barwach doskonałej jedności nie tylko ciała, ale i ducha mówiąc o nim jako o sakramencie:

„To jest ów wielki sakrament, z powodu którego opuści człowiek ojca swego i matkę swoją, a przyłączy się do żony swojej i będą dwoje, ale nie w jednym ciele, jak czytamy w Piśmie, lecz w jednym duchu (Rdz 2, 24)"5.

Wyrazem troski o świętość małżeństwa było, według niego, surowe traktowanie grzechów zagrażających jego nierozerwalności. Hieronim kierował się w tym względzie potężną wówczas tendencją do tworzenia przeciwwagi dla wielu teorii, głoszonych przez osoby mające relatywne podejście do zagadnień związanych z moralnością i etyką seksualną; zwracając się do odbiorców swoich listów, pisał:

„Nie powinniśmy bowiem spoglądać na przykłady tłumu, który nie przestrzega karności obyczajów i nie trzyma się żadnej reguły, a nie tyle powoduje się rozumem, ile pozwala się unieść prądowi. I nie należy nam naśladować tych, którzy pod imieniem chrześcijańskim wiodą pogańskie życie i co innego głoszą wyznaniem, a co innego postępowaniem [...]. Chrześcijanin powinien się różnić od poganina nie tylko wiarą, ale życiem, i za pomocą odmiennych uczynków wykazywać odmienność religii. [...] Niechaj więc między nami a nimi będzie jak największy rozdział. Niechaj błąd wyraźnie będzie oddzielony od prawdy. Niech ubiegają się o rzeczy ziemskie ci, którzy nie mają obietnic niebieskich; niech oddają się całkowicie temu krótkiemu życiu ci,

${ }^{2}$ Por. H. Insadowski, Rzymskie prawo matżeńskie a chrześcijaństwo, Lublin 1935, 237-240, 295-297, 304-305, 313-314; M. Woźniak, Cudzołóstwo, w: Słownik matzeństwa i rodziny, Warszawa - Łomianki 1999, 64-65.

${ }^{3}$ Por. Hieronymus, Epistulae 79, 10.

${ }^{4}$ Por. tamże 66,3 .

${ }^{5}$ Tamże 22, 1, CSEL 54, 145, tłum. J. Czuj: Św. Hieronim, Listy, I-III (= Czuj I-III), Warszawa 1952-1954; tu Czuj I 111. 
którzy nie znają rzeczy wiecznych; niech nie lękają się grzeszyć [...], niech służą występkom ci, którzy nie spodziewają się przyszłych nagród za cnoty. My zaś, którzy na podstawie najczystszej wiary wyznajemy, że każdy człowiek musi stanąć przed trybunałem Chrystusowym [...], powinniśmy trzymać się z dala od grzechów. [...] Niechaj nie idą za błądzącą rzeszą ci, którzy wyznają, że są uczniami Prawdy".

W tak delikatnej sprawie, jaką jest zachowanie wzajemnego posłuszeństwa między małżonkami potrzeba, aby oparte było ono przede wszystkim na zasadzie okazywanej życzliwości i miłości, niż na surowości i strachu ${ }^{7}$, bo to przecież w większości przypadków ów strach i surowość którejś ze stron, mogą stać się przyczyną któregoś z wykroczeń przeciw małżeństwu.

Hieronim poucza, że żony mają pozyskiwać swoich mężów do zrozumienia roli małżeństwa, jako czegoś wznioślejszego, niż tylko kontraktu cielesnego. Na potwierdzenie swojego toku myślenia przytacza słowa zaczerpnięte z I listu św. Piotra:

„«Podobnie i niewiasty niech będą poddane mężom, aby nawet ci, którzy nie wierzą słowu [Ewangelii], przez postępowanie kobiet pozyskani byli bez słowa» $(1 \mathrm{P} 3,1)$. Jeśli więc także pogańskim małżonkom należy się cześć na mocy małżeństwa, to o ileż bardziej należy ją oddać chrześcijańskim"8.

Nasz Moralista zauważa, że wśród pogan krystalizuje się podobny do chrześcijańskiego pogląd na instytucje małżeńską, gdzie rola małżonków skupia się na budowaniu i pogłębianiu wzajemnych relacji na takich wartościach, jak: zaufanie, przyjaźń i szacunek ${ }^{9}$; pisząc zaś o tego rodzaju zasadach, ma być może na myśli wymiar wolności moralnej, w której głównym punktem odniesienia jest dar mądrości, biorący udział w procesie wewnętrznego odczuwania tejże wolności. Powszechne było przecież wówczas stwierdzenie, że ten prawdziwie jest wolny, kto postępuje roztropnie, co Hieronim przedstawia w słowach:

„Oto panny złe, które dziewictwo zachowują tylko na ciele, a nie na duszy; oto panny głupie, które nie mając oleju odłączone są od oblubieńca"10.

Niewątpliwie, jedną z ważniejszych cnót chrześcijańskich, wyrastających z połączenia mądrości z roztropnością w przestrzeganiu zasad wolności moralnej, jest czystość obyczajów, która nie tylko pomnaża tę wolność, ale, zdaniem Strydończyka, potrafi uczynić człowieka rzeczywiście wolnym. Oprócz męż-

\footnotetext{
${ }^{6}$ Tamże 148, 8-9.

${ }^{7}$ Por. tamże 148, 25-26; 49, 8.

${ }^{8}$ Tamże 148, 26, CSEL 56, 351, Czuj III 464-465.

${ }^{9}$ Por. R. Wiśniewski, Św. Augustyn -św. Hieronim o konkubinacie i malżeństwach ludzi rozwiedzionych, „Mówią Wieki” 37 (1994) z. 3, 3-4.

${ }^{10}$ Hieronymus, Epistulae 22, 5, CSEL 54, 150, Czuj I 115.
} 
czyzn bowiem, namawia on często kobiety, aby gdy już otrzymają od Boga łaskę w wymiarze owej wolności, nie pogrążały się same w niewoli grzechu pożądliwości, to jest skłonności do spraw czysto ziemskich znajdujących swoje odzwierciedlenie m.in. w ubiorze i sposobie realizacji osobistych pragnien ${ }^{11}$. Tenże troskliwy kierownik duchowy świadom jest, że przez grzech człowiek staje się umarłym i niewolnikiem, ale też wierzy, że nawrócenie i szczery żal oczyszcza $z$ dawnych występków ${ }^{12}$. Zachęca więc wszystkich chrześcijan do walki z własnymi słabościami oraz wzywa do ich przezwyciężania, zdając sobie sprawę z trudności, które czekają tego, co podejmuje się takiego trudu, gdyż sam doświadczył ciężaru walki z tym, który chciał go odłączyć od Chrystusa $^{13}$. Zapewnia jednak, że ci, którzy podejmują taką walkę z własnymi słabościami, mogą być pewni, że potem Ten, w którego imię walczyli pozwoli im cieszyć się zasłużonym i godnym chwały zwycięstwem. Przypomina, że te trudy walki nie są nigdy bezużyteczne, ale ochraniają od wiecznej niewoli:

„Czy nie lepiej jest przez krótki czas wojować, trzymać straż na wałach, nosić broń, trudzić się w pancerzu, a potem cieszyć się jako zwycięzca, aniżeli za niecierpliwość jednej godziny być na wieki niewolnikiem?"14.

Na równi zatem, gdy sprawa dotyczy małżonków chrześcijańskich, jak i pogańskich, brak którejś z podanych wcześniej wartości może powodować powolne naruszanie jedności małżonków. Nastawienie ponadto niektórych mężczyzn tylko na możliwość zaspokajania własnych pożądań seksualnych, podobnie jak i wielu kobiet, stawało się głównym powodem szeregu wykroczeń przeciw małżeństwu.

Św. Hieronim nie zajmował się oddzielnie żadnym z tego rodzaju wykroczeń, stąd omówienie ich, jak też ukazanie osobistego jego stosunku do nich, będzie jedynie próbą ogólnego przedstawienia możliwie wszystkich ówczesnych wykroczeń, nawet tych, które są tylko podane jako hipotetyczne, ale niekoniecznie obecnych w sposób bezpośredni w środowisku jego oddziaływania. Z informacji, jakie pozostawił $\mathrm{w}$ swoich listach, wyróżnia się się wykroczenie zwane cudzołóstwem, jako to, które wyrasta lub też może wyrastać na podłożu określonej dewiacji seksualnej. I tak w liście do Amanda czytamy:

„Cudzołożnicą jest niewiasta, która za życia męża wychodzi za innego [...]. Dopóki mąż żyje, choćby był cudzołożnikiem, choćby sodomitą, choćby wszystkimi obarczony występkami i przez żonę z powodu tych zbrodni opuszczony, uważany jest za męża tej, której innego męża brać nie wolno"15.

\footnotetext{
${ }^{11}$ Por. tamże 54, 7 i 13.

${ }^{12}$ Por. tamże 118, 6.

${ }^{13}$ Por. tamże 22, 30.

${ }^{14}$ Tamże 22, 39, CSEL 54, 206-207, Czuj I 159.

${ }^{15}$ Tamże 55, 4, CSEL 54, 493, Czuj I 388-389.
} 
Na wstępie trzeba zaznaczyć, że chodzi tu o powtórne małżeństwo, a ta jednostronność Hieronima jest jedynie pozorna, inaczej występowałby z tezą, która zaprzeczałaby jego poglądom na temat zwyczajów i praw pogańskich oraz ich stosunku do osobnych praw odnoszących się do mężczyzn, a jeszcze innych względem kobiet ${ }^{16}$. W liście skierowanym do Oceana przychodzi z dalszym i jednoznacznym wyjaśnieniem:

„Nie może być opuszczona żona cudzołożna, a mąż cudzołożny zatrzymany [...]. Inne są prawa Cezarów, inne Chrystusa. Co innego nakazuje Papinianus, a co innego święty Paweł. Tamci dozwalają na bezwstyd mężczyznom, a ponieważ potępiają jedynie gwałt i cudzołóstwo, na każdym kroku pozwalają na rozpustę w domach publicznych i w stosunku do młodych służebnych, jak gdyby winę godność stanowiła, a nie chęć"17.

Aby uzyskać jeszcze większą czytelność, trzeba zwrócić uwagę na jeszcze jedną wypowiedź, zawartą w tymże liście:

„Cokolwiek nakazane jest mężczyznom, to również odnosi się i do niewiast"18.

W kontekście tego czytelnym staje się też stwierdzenie odnośnie cudzołóstwa w liście skierowanym do Amanda. Analizując słowa: „Cudzołożnicą jest niewiasta, która za życia męża wychodzi za innego" można wnioskować, że każda osoba, bez względu na płeć, zawierająca drugie małżeństwo za życia poprzedniego współmałżonka, popełnia cudzołóstwo. Aby jednak lepiej zrozumieć to, co miał na myśli nasz Ojciec Kościoła, trzeba wyjaśnić pojęcie bigamii, jak i dokonać pewnych uwag niezbędnych do wyjaśnienia podjętego problemu.

2. Bigamia. Kolejnym wykroczeniem przeciw jedności małżeńskiej jest tzw. bigamia (dwużeństwo), potępiana również przez prawo rzymskie, a rozumiana m.in. jako zawarcie małżeństwa przez osoby, z których co najmniej jedna jest już zaangażowana w inny, monogamiczny, legalny związek małżeński ${ }^{19}$; szczególną postacią bigamii jest też sytuacja, gdy oboje małżonkowie pozostają już w małżeństwie - wówczas ma miejsce bigamia podwójna ${ }^{20}$. Do wyjątkowego rodzaju bigamii należy również wielożeństwo, a także bigamia

${ }^{16}$ Por. W. Panewki, Secundae nuptiae w życiu i prawie starożytnych chrześcijan, PK 14 (1971) nr 1-2, 259-260.

${ }^{17}$ Hieronymus, Epistulae 77, 3, CSEL 55, 39, Czuj II 160; Papinianus († 212) - jeden z najwybitniejszych prawników rzymskich, autor szeregu dzieł odznaczających się jasnością i precyzją wywodu prawnego (Quaestiones, Responsa, Definitiones, De adulteriis), stracony na rozkaz Karakalli.

${ }^{18}$ Hieronymus, Epistulae 77, 3, CSEL 55, 39, Czuj II 160.

${ }^{19}$ Por. K. Olechnicki, Stownik socjologiczny, Toruń 1997, 29; Insadowski, Rzymskie prawo matżeńskie, s. 156-158.

${ }^{20}$ Por. R. Krajewski, Bigamia w prawie polskim i prawie kanonicznym, Włocławek 2003, 11. 
kolejna, kiedy jedno z małżonków po śmierci drugiego, zawiera nowe małżeństwo, oraz bigamia jednoczesna, kiedy jedno z małżonków zawarło drugie małżeństwo za życia drugiego $\mathrm{z}$ nich ${ }^{21}$. Zgodnie z tym, o czym dowiadujemy się z listów Hieronima, w sytuacji bigamii kolejnej, jeśli pierwsze małżeństwo uważane było za ważne i godziwe, drugie było dopuszczane, ale zgodnie z tradycją wczesnochrześcijańską, odradzane, ponieważ świadczyło o nadmiernej niepowściągliwości sprzeciwiającej się prawu Bożemu, prawu doskonałej jedności, której odblaskiem winna być jedność małżonków chrześcijańskich. Tym co by potwierdzało powyższą tezę, jest wydarzenie, z którym zetknął się sam Hieronim, gdy był sekretarzem biskupa Rzymu - Damazego ${ }^{22}$ :

„Przed wielu laty, gdym pomagał biskupowi Rzymu Damazemu [...] widziałem parę ludzi złożoną z wyrzutków społeczeństwa. Mężczyzna pochował już dwadzieścia żon, kobieta miała dwudziestego drugiego męża. Połączyli się oni węzłem małżeńskim, który uważali za ostatni. Wszyscy mężczyźni, jak i kobiety oczekiwali, kto z nich po tylu przejściach pochowa towarzysza. Zwyciężył małżonek i przy napływie ludzi z całego miasta kroczył przed marami wieloślubnej małżonki, [...] wpośród okrzyków rozlegających się na jego cześćc"

Hieronim pisząc o bigamistach zdaje się sugerować, iż są oni wyrzutkami społeczeństwa. Szerzej zarysowana terminologia pojęcia bigamii pozwala zrozumieć, dlaczego Hieronim, w kontekście epoki, w której przyszło mu żyć, dystansuje się od twierdzeń, iż zawieranie powtórnych małżeństw jest konieczne. Dokonuje pewnego rozróżnienia, nie dopuszcza dwużenności, natomiast dopuszcza powtórne małżeństwo w przypadku, gdy jedna ze stron umrze. Rozwijając ten temat, zagadnienie powtórnego małżeństwa zakreślić można wokół czterech przypadków: bezdzietnej młodej wdowy, wdowy z dziećmi, bezdzietnej rozwódki, która przeszła na chrześcijaństwo, oraz tej, która oddaliła się od swego męża, aby żyć z konkubentem. Nasz Doktor Kościoła w liście do Ageruchii zaleca młodym wdowom, które nie posiadają potomstwa, w myśl słów św. Pawła, że jeśli miałaby „gorzeć”, niech raczej powtórnie wyjdą za mąż, żeby „rodziły dzieci i były gospodyniami, nie dając przeciwnikom żadnego powodu do obmowy"24. Zgodnie z tymi słowami małżeństwo po śmierci współmałżonka jest wysoce usprawiedliwione, ale według Hieronima niegodne, bowiem pojęcie małżeństwa w świetle jego słów, nie posiada tylko i wyłącznie wymiaru ziemskiego, ale jest też nośnikiem życia dla Królestwa Bożego. Słusznym w tym wypadku wydawałoby się stwierdzenie, że powtórne małżeństwo jest niewiernością względem zmarłego

\footnotetext{
${ }^{21}$ Por. tamże.

22 Por. A. Bober - J. Wzorek, Damazy, EK III 987-988; J.N.D. Kelly, Hieronim, tłum. R. Wiśniewski, Warszawa 2003, 96-108 (Na dworze Damazego).

${ }^{23}$ Hieronymus, Epistulae 123, 9, CSEL 56, 82-83, Czuj III 223-224.

${ }^{24}$ Tamże 123, 3, CSEL 56, 74, Czuj III 216.
} 
małżonka, gdyż celem ostatecznym jest jedność ducha pierwszego małżeństwa ${ }^{25}$. Hieronim poruszając tego typu zagadnienia, nie obawia się wskazać na fakt stosowania w niektórych życiowych sytuacjach pewnej gradacji, która umożliwia człowiekowi podejmowanie bardziej godziwych wyborów. Tak więc zgodnie z jego myślą zawarcie powtórnego małżeństwa jest o wiele lepsze i przyzwoitsze od nierząa ${ }^{26}$. Młoda wdowa, która wykazuje słabość w opanowaniu siebie, nie powinna oddawać się rozpuście poprzez obcowanie z wieloma kochankami, ale mieć jednego męża: zamiast dopuszczania się rozpusty, powinna oddawać się rodzeniu dzieci, aby nie odczuwała lęku przed poczęciem dziecka, które byłoby owocem grzechu i skłaniało ją do zabójstwa ${ }^{27}$. Ta swoistego rodzaju surowość i rygoryzm nacechowane są miłością, niemalże miłosierdziem, które Hieronim zachował i zastosował w stosunku do chrześcijan, nie znających jeszcze dobrze „prawa Ewangelii.” Dla tych wiernych, w większości osób młodych ${ }^{28}$, dopuszczał pewną dozę tolerancji, czego przykładem może być niejaka Fabiola - chrześcijanka, która jeszcze za życia swego męża, zawarła nowe małżeństwo, dopuszczalne u pogan przez prawo rzymskie, ale nie do przyjęcia przez chrześcijan:

„dla niewiast chrześcijańskich za życia męża są przecięte wszelkie możliwości drugiego zamążpójścia [...]"’29.

Wraca tu jak bumerang jego wypowiedź z listu do Amanda:

„Dopóki mąż żyje, choćby był cudzołożnikiem, choćby sodomitą, choćby wszystkimi obarczony występkami i przez żonę z powodu tych zbrodni opuszczony, uważany jest za męża tej, której innego męża brać nie wolno"30.

Ze względu jednak na jej młodość i naturalną jej pożądliwość, nasz Moralista szuka dla niej usprawiedliwienia wyjaśniając, że: „mąż jej był cudzołożnikiem" i dodając:

„Była bardzo młoda, nie mogła zachować swojego wdowieństwa, widziała inne prawo w członkach swoich, sprzeczne z prawem jej umysłu, i czuła w sobie nieprzeparte pragnienie życia zmysłowego. Wolała więc wyznać otwarcie słabość swoją i zasłonić się jakimś cieniem nędznego małżeństwa, niż cieszyć się sławą jednomężnej i uprawiać nierząd"31.

Wywód ten zakłada, że lepszy jest według niego nawet cudzołożny związek monogamiczny, niż rozwiązłość; relatywną wartość zachowuje w nim bowiem

${ }^{25}$ Por. tamże 148, 2.

${ }^{26}$ Por. tamże 79, 10, CSEL 55, 100, Czuj II 223: „[...] powtórne małżeństwa, [...] mają pierwszeństwo przed domami publicznymi”.

${ }^{27}$ Por. tamże 22, 13.

${ }^{28}$ Por. tamże 79, 7.

${ }^{29}$ Tamże 77, 3, CSEL 55, 40, Czuj II 161.

${ }^{30}$ Tamże 55, 4, CSEL 54, 493, Czuj I 389.

${ }^{31}$ Tamże 77, 3, CSEL 55, 39, Czuj II 160-161. 
wierność partnerów i mniejsze zgorszenie. $Z$ reguły tacy ludzie byli całkowicie wyłączani ze wspólnoty Kościoła, zatem oddalenie się od współmałżonka, oznaczało także oddalenie się od wspólnoty, która była jednocześnie wspólnotą stołu Bożego. ${ }^{32}$ Osoby takie nie mogły nawet wstępować w szeregi pokutujących, bowiem warunkiem takiego wstąpienia było zerwanie cudzołożnego związku lub rozwiązująca pierwsze małżeństwo śmierć współmałżonka ${ }^{33}$. Swięty Hieronim, wierny naśladowca św. Pawła, postępowanie Fabioli określił jako nierozważne, a z drugiej strony w pewnym sensie rozsądne; bo ,przez nierozwagę otrzymała jedna ranę, podczas gdy uniknęła wielu ran, które szatan zadaje" 34 . Tymi ranami są chociażby zabójstwa jeszcze nienarodzonych dzieci (homicidium $^{35}$ ), staranie się o bezpłodność lub stosowanie różnych trucizn na spędzenie płodu w przypadku, gdy jest on owocem występku, a nadto, przy stosowaniu tego typu działań, możliwe samobójstwo ${ }^{36}$. Kontynuując myśl dochodzimy do punktu krytycznego, do granicy, gdzie występek z jednorazowego aktu przechodzi w notoryczne postępowanie. W takim wypadku będziemy mieli do czynienia z prostytucją. Zanim jednak przejdę do wyjaśnienia jej złożoności, chcę jeszcze krótko zwrócić uwagę na akt cudzołóstwa, który podejmowany przez kobiety, a w sposób szczególny przez mężczyzn, wynika z niepohamowanego i pospolitego zaspakajania tak zwanych osobistych potrzeb seksualnych ${ }^{37}$, niejednokrotnie o cechach wynaturzenia, ${ }^{38}$ które w sposób niejasny mogą kryć się nawet pod pojęciem sodomii ${ }^{39}$. Dla uzyskania jasności w tej kwestii zaznaczyć trzeba, że tym pojęciem określano skłonności, które dzisiaj określano by, jako biseksualne, homoseksualne, jak i też transseksualne. Omówienia tej złożoności podejmę się w dalszej części artykułu.

3. Prostytucja, zgodnie $\mathrm{z}$ myślą Hieronima, jak i klasyczną definicją prawa rzymskiego, sformułowanego przez Ulpiana ${ }^{40}$, to efekt notorycznego podejmowania się aktu nierządu, bądź to dla zaspokojenia własnych potrzeb seksualnych $^{41}$, bądź też w celach zarobkowych ${ }^{42}$. Najczęściej osobami trud-

32 Por. tamże 22, 29.

${ }^{33}$ Por. tamże 55, 4.

34 Tamże 77, 3, CSEL 55, 40, Czuj II 161.

${ }^{35}$ Por. H. Kupiszewski, Powtórne matżeństwo w konstytucjach cesarzy rzymskich w IV $i$ Vieku, AnCra 7 (1975) 364-365.

${ }^{36}$ Por. Hieronymus, Epistulae 22, 13; zob. M. Starowieyski, Ze świata wczesnego chrześcijaństwa, Pelplin 1998, 220-223.

37 Por. Hieronymus, Epistulae 50, 1-5; 77, 3; zob. J. Troska, Moralność życia cielesnego (= Biblioteka Pomocy Naukowych. Wydział Teologiczny UAM, t. 14), Poznań 1999, 116.

${ }^{38}$ Por. M. Graczyk, Prostytucja, w: Stownik matzeństwa i rodziny, s. 369.

${ }^{39}$ Por. Hieronymus, Epistulae 55, 4.

${ }^{40}$ Por. Graczyk, jw.

${ }^{41}$ Por. Hieronymus, Epistulae 49, 8, CSEL 54, 363: „Uni homini prostitutam esse quam multis”.

42 Por. tamże 22, 6, CSEL 54, 150-151, Czuj I 115-116: „[...] owe panny [...] wystawiły na sprzedaż członki Chrystusa i zmieniły świątynię Ducha Świętego w dom rozpusty? [...] odkryje się 
niącymi się tą profesją w celach zarobkowych były kobiety. Ich bowiem status społeczny w starożytności był w praktyce zawsze niższy od tego, który przysługiwał mężczyznom. Im to też, jak czytamy w Hieronimowym liście do Oceana, „prawa Cezarów” zezwalały na bezwstyd, to jest na ,rozpustę w domach publicznych w stosunku do młodych służebnych, jak gdyby winę stanowiła godność, a nie chęć" ${ }^{43}$.

4. Gwałt. Niewątpliwie Hieronim porusza też w tym wypadku zagadnienie gwałtu, który według nowożytnej definicji jest „,naruszeniem porządku moralnego i biologicznego, gdyż jest działaniem niesprawiedliwym, które godzi w godność osoby oraz w porządek miłości" ${ }^{4}$. Hieronim mając to na uwadze napomina swoich adresatów, w głównej mierze kobiety, aby nie gardziły swoją płcią, albowiem Pismo Święte chwali życie niewiast, natomiast potępia zachowania mężczyzn ${ }^{45}$. Owa jednostronność „prawa Cezarów”, doskonale ukazana została przez Hieronima w napisanym ok. 370 r. liście do przyjaciela Innocentego, gdzie jest mowa o fałszywym oskarżeniu o cudzołóstwo żony przez męża, a także o konsekwencjach prawnych z tego wynikających. Pod wpływem tortur niesłusznie oskarżany młodzieniec przyznaje się do niepopełnionego czynu, niewiasta natomiast zaprzecza. Zaprowadzeni na miejsce stracenia - młodzieniec ginie od miecza, kobieta zaś zostaje ocalona ${ }^{46}$. Hieronim zauważa, że w przypadku ludzi młodych i niedoświadczonych jeszcze życiem, sprawy związane z życiem seksualnym są bardzo delikatną sprawą, bez względu na płeć czy status społeczny. On sam wspominając fragmentarycznie swoje życie z młodości nie kryje faktu, że i on poddawał się jakimś występkom rozwiązłości $\mathrm{i}^{47} \mathrm{~W}$ częstym przebywaniu $\mathrm{w}$ towarzystwie dziewcząt $\mathrm{z}$ ukierunkowanym właściwym młodemu człowiekowi pożądaniem względem nich ${ }^{48}$, co jednakże nie jest żadną formą usprawiedliwienia, a raczej efektem zaniedbania rodziców w kwestii wychowania, owocem czego są grzechy, których dopuszczają się młodzi ludzie, które jednak „idą na rachunek rodziców"49. Skutki tego widać także nawet u ludzi związanych z Kościołem:

„Przykro mówić, ile dziewic upada codziennie, ile ich traci Kościół Matka [...] jak bardzo wiele jest wdów, które [...] okrywają swe nieszczęsne sumie-

sromota [...], i patrzeć będzie na swą nędzę [...], i wystawi nogi swoje przed każdym przechodniem, i będzie splugawiona".

${ }^{43}$ Tamże 77, 3, CSEL 55, 39, Czuj II 160..

${ }^{44}$ M. Graczyk, Gwalt, w: Stownik matżeństwa i rodziny, s. 158-159.

${ }^{45}$ Por. Hieronymus, Epistulae 65, 2.

${ }^{46}$ Por. tamże 1, CSEL 54, 1-9, Czuj I 1-8.

${ }^{47}$ Por. tamże 2, 1.

${ }^{48}$ Por. tamże 22, 7 i 11.

${ }^{49}$ Tamże 107, 6, CSEL 55, 297: „mala eius quam bona parentibus imputantur”. 
nie kłamliwą szatą i chodzą z podniesioną głową, tanecznym krokiem, jeśli ich nie zdradza nabrzmiałość brzucha czy kwilenie dzieci"s0.

Tenże Ojciec Kościoła dodaje, że oprócz osób, które przez brak dostatecznej znajomości „praw Ewangelii” same wykluczają się z Kościoła, są również i takie, które świadomie to czynią, wykluczając swoje nawrócenie ${ }^{51}$, a winę za to ponoszą często matki nie dając dzieciom dobrego przykładu i zaniedbując ich wychowanie $^{52}$. W liście skierowanym do jakiejś matki i jej córki przebywających w Galii pisał:

„proszę was o zgodę, aby was inni nie podejrzewali. [...] Matka i córka, symbole rodzinnej miłości, wyrazy obowiązku, więzy natury i związek drugi po łączności z Bogiem!"’33.

W wychowaniu swoich dzieci, zwłaszcza w okresie ich dojrzewania, matka winna odznaczać się stanowczością, a nawet surowością i wyżej w nim stawiać Boga, niż ich zachcianki:

„Jeśli u dziewicy Bożej gani ktoś nie rozwiązłość, lecz twardość, to surowość ta jest pobożnością. Stawiasz bowiem wyżej nad matkę tego, którego masz obowiązek stawiać wyżej i nad duszę swoją. Jeśli i matka podobnie będzie myślała, odczuje w tobie córkę i siostrę" ${ }^{54}$.

Matka, żyjąca nawet we wdowieństwie, nie jest zwolniona od obowiązku dawania dobrego przykładu swoim dzieciom, a gdy zauważy u dziecka jakąś ułomność lub skłonność do złego, ma obowiązek zaraz go korygować i upominać, aby nie dopuścić do późniejszego zgorszenia, które mogłoby się przyczynić do zniekształcenia prawdziwego oblicza Kościoła:

„Bardziej ci przystoi znosić raczej winę córki niż szukać sposobności do własnej. [...] Jesteś już w tym wieku, że mogłabyś mieć wnuki z córki [...]. Niech ona wróci z mężczyzną, chociaż wyszła sama; powiedziałem z mężczyzna, nie $z$ małżonkiem; nikogo nie należy oczerniać. Chciałem zaznaczyć płeć, nie małżeństwo" ${ }^{55}$.

Doszukiwać się tu można pośrednio zazdrości matki względem córki o tego samego mężczyznę. Nasz Autor listu pouczając owe kobiety, występuje tu jak troskliwy ojciec zauważając zapewne niebezpieczeństwo zaistnienia w przyszłości związku kazirodczego ${ }^{56}$.

\footnotetext{
${ }^{50}$ Tamże 22, 13, CSEL 54, 160, Czuj I 123; zob. też 49, 17, CSEL 54, 381, Czuj I 299-301.

${ }^{51}$ Por. tamże $122,1$.

52 Por. tamże 39, 6.

${ }^{53}$ Tamże 117, 2, CSEL 55, 424, Czuj III 73.

${ }^{54}$ Tamże 117, 4, CSEL 55, 427, Czuj III 75.

55 Tamże 117, 11, CSEL 55, 433, Czuj III 80.

56 Por. tamże 123, 17.
} 
5. Kazirodztwo ${ }^{57}$. W cytowanym wyżej liście do dwóch galijskich kobiet Hieronim upomina najpierw córkę, by porzuciła młodzieńca, z którym się związała, a według ,praw Ewangelii” nie może z nim zawrzeć małżeństwa, bo traci dla niego majątek i dobre imię, a on, który ze względu na wiek nie może być dla niej wychowawcą i opiekunem, i tak ją zostawi i znajdzie sobie młodszą i bogatszą, oraz zachęca ją, by wróciła do matki. Upomina również jej matkę, która zdaje się kochać w tym młodzieńcu, by szanowała swój wiek i dobre imię, by nie szukała w nim pociechy, nie budziła w sobie już wygasłych pragnień i nie grzeszyła, obawiając się zapewne, że może to być grzech kazirodztwa (choć nie używa tej nazwy) surowo potępianego od wieków przez prawo rzymskie ${ }^{58} \mathrm{i}$ boskie. Zachęca matkę, by zamieszkała razem $\mathrm{z}$ córką i synem, który jest mnichem:

„Nie podejrzewam Cię, jakobyś była niedbała, zuchwała, pełna pogardy, chociaż mając dwadzieścia pięć lat zamknęłaś w swych ramionach jakby w kleszczach młodzieńca, któremu ledwie zaczęła rosnąć broda. Rzeczywiście wspaniały z niego wychowawca, który by cię napominał, przerażał groźnym spojrzeniem! Wprawdzie żaden wiek nie zabezpiecza przed żądzą, jednak siwizna broni przynajmniej przed wyraźną hańbą. Przyjdzie, przyjdzie czas, nadejdzie dzień - ani się nie spostrzeżesz - a ten twój śliczny chłopiec znajdzie sobie bogatszą albo młodszą; kobiety bowiem szybko się starzeją, zwłaszcza te, które przebywają obok mężczyzn. Żałować będziesz swego zamiaru i zbrzydnie ci upór, kiedy stracisz i majątek, i dobre imię, kiedy łatwo się rozerwie związek, który był źle złączony [...]. Ty również, matko, chociaż ze względu na wiek nie boisz się obmowy, nie sądź, że ci wolno grzeszyć. Niech raczej córka uczy się od ciebie niż ty od niej, jak należy się rozłączać. Masz syna, córkę i zięcia, a raczej współmieszkańca córki swojej; po co szukasz pociechy u obcych i zapalasz ognie już wygasłe? Bardziej ci przystoi znosić raczej winę córki niż szukać sposobności do własnej. Niech będzie z tobą syn mnich, obrona uczciwego postępowania i wdowieństwa. Po co ci obcy człowiek, zwłaszcza w tym domu, w którym nie mógł się zmieścić syn i córka. Jesteś już w tym wieku, że mogłabyś mieć wnuki z córki”'59.

Jeszcze wyraźniej przybliża nam Hieronim grzech kazirodztwa przez przypomnienie historii pijanego Lota i jego córek (Rdz 19, 30-37) z podkreśleniem, że ci, którzy się go dopuszczają „na wieki nie wejdą do Kościoła Bożego”. Córki Lota będąc przekonane, że w potopie zginął cały rodzaj ludzki, w tym również wszyscy mężczyźni, którzy mogliby go wzbudzić, zapragnęły mieć dzieci. Wiedziały, iż ich ojciec Lot jest zbyt sprawiedliwy, by mógł tego z nimi

${ }^{57}$ Por. M. Gołębiewski, Kazirodztwo, w: Stownik małzeństwa i rodziny, s. 190-191.

${ }^{58}$ Insadowski, Rzymskie prawo matżeńskie, s. 182 i 187; J. Misztal-Konecka, Incestum w prawie rzymskim, Lublin 2007.

${ }^{59}$ Hieronymus, Epistulae 117, 10-11, CSEL 55, 433, Czuj III 80. 
świadomie dokonać. Spiły go więc, współżyły z nim i poczęły, dopuszczając się kazirodztwa:

„[...] Lota, cieszącego się przyjaźnią Boga, ocalonego na górze i uznanego za jedynego sprawiedliwego spośród tylu tysięcy ludzi, spoiły własne córki; a chociaż mniemały one, że skończył się rodzaj ludzki, i uczyniły to raczej z chęci posiadania dzieci niż z pożądliwości, to jednak wiedziały, iż mąż sprawiedliwy nie popełniłby takiego czynu będąc trzeźwym. Nie miał on wprawdzie świadomości tego, co czyni, jednak chociaż występek jego nie był dobrowolny - to w przewinieniu tkwi zło. Z niego rodzą się Moabici i Ammonici, nieprzyjaciele Izraela, którzy aż do czwartego i dziesiątego pokolenia, i na wieki nie wejdą do Kościoła Bożego" ${ }^{60}$.

Oprócz powyższych Hieronim w swojej korespondencji wzmiankuje także inne występki seksualne, jak: sodomia, biseksualizm, homoseksualizm i transeksualizm - przestępstwa ściśle ze sobą powiązane, wręcz nie do rozdzielenia, gdyż jedno było konsekwencją poprzedniego. Gdy chodzi o to ostatnie, uważa je za zachowanie godne pożałowania i ubolewa, że kobiety upodabniają się do mężczyzn ${ }^{61}$, a mężczyźni do kobiet:

„Unikaj też mężczyzn, gdy ich ujrzysz obwieszonych łańcuchami, z niewieścimi - wbrew Apostołowi $(1$ Kor 11, 14) włosami, z kozią brodą, czarnym płaszczem i gołymi, mimo zimna, nogami. To wszystko są sztuki diabelskie"62.

6. Pedofilia. Innym wspominanym w listach Hieronima seksualnym przestępstwem jest określona $\mathrm{w}$ dzisiejszej słownikowej terminologii pedofilia, zwana też inaczej jako infantoseksualizm. Pedofilia, zgodnie ze współczesną terminologią słownikową, jest zaburzeniem zachowania seksualnego, które dotyczy tzw. obiektu, czyli partnera seksualnego, a przejawia się w skłonności do praktyk seksualnych z dziećmi. Najbardziej atrakcyjnym wiekiem dla pedofilów jest wiek ok. 10-12 lat ${ }^{63}$. Niektóre słowniki podają, że tego typu zaburzenia dotyczą tylko mężczyzn ${ }^{64}$, co jednak do końca nie jest prawdą ${ }^{65}$, o czym przekonuje nas list Hieronima, skierowany do kapłana Witalisa, w którym pisze:

„Słyszałem - świadkiem Pan, że nie kłamię - co następuje: Pewna kobieta wychowała znalezione dziecko, karmiła je i spełniała wobec niego obowiązki

${ }^{60}$ Tamże 22, 8, CSEL 54, 156, Czuj I 119-120.

${ }^{61}$ Por. tamże 22, 27, CSEL 54, 184, Czuj I 142: „Inne [...], w męskim odzieniu, wstydzą się być niewiastami, którymi się urodziły".

${ }^{62}$ Tamże 22, 28, CSEL 54, 185, Czuj I 143.

${ }^{63}$ Por. J. Kurzępa, Pedofilia. Formy przemocy seksualnej, w: Encyklopedia pedagogiczna XXI wieku, IV, Warszawa 2005, 308-309.

${ }^{64}$ Por. W. Bołoz, Pedofilia, w: Stownik matzeństwa i rodziny, s. 332.

${ }^{65}$ Por. Kurzępa, Pedofilia, s. 309-311. 
niańki. Chłopiec ów sypiał z nią, aż doszedł do dziesiątego roku. Zdarzyło się, że więcej, niż się godzi, wypiła wina, a rozpalona namiętnością, wyuzdanymi ruchami doprowadziła chłopca do obcowania z nią. Pierwsze pijaństwo powtórzyło się następnej nocy i weszło w zwyczaj. Przed upływem dwóch miesięcy kobieta stała się brzemienna. [...] Ze zrządzenia Bożego stało się, że ta, która wbrew naturze lekceważąc prawa Boże nadużywała prostoty chłopca, przez Pana natury została światu pokazana, gdy się spełniły te słowa: «Nic nie ma zakrytego, co by wyjawione być nie miało» (Łk 8, 17; Mt 10, 26)"66.

7. Wykroczenia seksualne osób duchownych. Osobną kategorią objąłem wykroczenia na tle seksualnym związane bezpośrednio ze środowiskiem życia osób duchownych, jak i samych duchownych; wykroczenia te miały inny ciężar gatunkowy, w sensie odpowiedzialności przed Bogiem. Jednym z ciekawszych ich przejawów, który swoje apogeum osiągnął właśnie w IV wieku, a swój początek miał już w II wieku, były tzw. „duchowe małżeństwa” lub synezaktyzm, polegający na zwyczaju wspólnego zamieszkiwania pod jednym dachem duchownego z kobietą, najczęściej dziewicą, nazywaną z tego powodu synezaktą lub agapetką, tworząc w ten sposób domową wspólnotę na podobieństwo małżeństwa ${ }^{67}$. Ten sposób życia duchownych budził jednak podejrzenia, a nawet zgorszenia, oraz wywoływał sprzeciw, czego dowodem na Wschodzie sa pisma św. Jana Chryzostoma ${ }^{68}$. Również Hieronim, który był wrażliwy na tego rodzaju sprawy, kierując się zdrowym rozsądkiem i ograniczonym zaufaniem do natury człowieka, spostrzegł, że jest to podatny grunt, na którym mogą pojawić się zgorszenia, które mogą ośmieszyć Kościół ${ }^{69}$. Sam osobiście znał przypadek takiego małżeństwa duchowego, kiedy to nie mieszkające razem matka i córka, „czy to z powodu samotności gospody, czy dla strzeżenia majętności przybrały sobie za opiekunów pewnych duchownych (quosdam clericos adsumpsissent),

${ }^{66}$ Hieronymus, Epistulae 72, 2, CSEL 55, 9-10, Czuj II 135.

${ }^{67}$ Por. P. de Labriolle, Le mariage spirituel dans l'antiquité chrétienne, ,,Revue Historique” 137 (1921) 205-255; H. Leclercq, Mariage spirituel, DACL X 2, 1881-1888; E. Magnin, Agapètes, DDC I 311-315; J. Gribomont, DPAC I 76.

${ }^{68}$ Por. Joannes Chrysostomus, Contra eos, qui subintroductas habent virgines, PG 47, 495-514, thum. R. Sawa: Przeciw duchownym mieszkającym wspólnie z dziewicami, VoxP 13-15 (1993-1995) t. 24-25, 415-446; tenże, Quod regulares feminae viris cohabitare non debeant, PG 47, 513-532, tłum. R. Sawa: Bogu poświęcone niewiasty nie powinny mieszkać z mężczyznami, VoxP 16 (1996) t. 30-31, 433-460; E.A. Clark, John Chrysostom and the subintroductae, ChH 46 (1977) 171-185; S. Longosz, Pisma przeciw synezaktom, VoxP 13-15 (1993-1995) t. 24-29, 337-365 (bibliografia).

${ }^{69}$ Por. Hieronymus, Epistulae 22, 14, CSEL 54, 161-162, Czuj I 124: „Wstyd, mówić, o zgrozo! Smutne to, lecz prawdziwe; którędy weszła do kościołów zaraza agapetek? Skądże ta zmiana nazwiska bez małżeństwa? Cóż to za nowy rodzaj nałożnic? [...]. Skąd te jednomężne nierządnice? W tym samym domu, [...] mieszkaniu, a często i w jednym sypiają łóżku i nazywają nas podejrzliwymi, jeśli wyrażamy z tego powodu obawę". 
tak że oddalone od siebie łączyły się ku większej hańbie z obcymi" 70 i listownie prosił je o porzucenie tego sposobu życia ${ }^{71}$.

Znał też dobrze naturę człowieka, która nie przygotowana odpowiednio do życia w ascezie, łatwo może ulec wpisanej w nią pożądliwości ${ }^{72}$. Stąd też w praktykowaniu tej formy życia widział również niebezpieczeństwo łatwego usprawiedliwiania się osób duchownych - jak i tak zwanych świeckich dzielących z nimi wspólny dach - ze swoich skłonności do ulegania rozwiązłego stylu życia ${ }^{73}$. Nic więc dziwnego, że ze względu na dobro Kościoła potępia ten sposób życia jego ludzi, gani, a nawet nie szczędzi różnego rodzaju inwektyw $^{74}$. Oprócz tzw. małżeństw duchowych Hieronim ostro potępia zdarzające się przypadki uwodzenia przez duchownych kobiet, nierzadko nawet Bogu poświęconych. W jednym z zachowanych listów ostro piętnuje zachowanie się diakona, nijakiego Sabiniana, który uwodząc kobiety zamężne współżył $\mathrm{z}$ nimi ${ }^{75}$, kierując się niepohamowanym pożądaniem chodził po domach publicznych $^{76}$, a jakby tego nie było dosyć, uwiódł jeszcze dziewicę poświęconą na służbę $\mathrm{Bogu}^{77}$, $\mathrm{z}$ którą prawdopodobnie, jak przypuszcza, mógł się nawet dopuścić się stosunku seksualnego ${ }^{78}$. Z listu tego wynika również, że ów nieszczęsny diakon popadł także w pewnego rodzaju zaburzenie preferencji seksualnej, współcześnie nazywanej fetyszyzmem ${ }^{79}$. Hieronim jednakże zatroskany o zbawienie każdego, wzywa także i jego do nawrócenia, dostrzegając

${ }^{70}$ Tamże 117, 1, CSEL 55, 422-423, Czuj III 71-72.

${ }^{71}$ Por. tamże 117, 9, CSEL 55, 422-423, Czuj III 79: „Bądź przynajmniej uczciwsza w stosunkach ze swoim towarzyszem. Rozłączcie swoje mieszkania, nie jadajcie razem, aby złośliwi ludzie nie posądzali was, że mieszkając pod jednym dachem i łoże macie wspólne”.

${ }^{72}$ Por. tamże 22, 11 oraz 38, 3, CSEL 54, 291, Czuj I 224: „Niech się rumieni ze wstydu kobieta chrześcijanka, jeśli wymusza wdzięk na naturze, jeśli troszczy się o ciało dla pożądliwości, której gdy ktoś podlega, nie może [...] podobać się Chrystusowi”; 52, 5; 54, 15, CSEL 54, 470, Czuj I 379: „Żadna kobieta nie idzie za mąż, by nie spała z małżonkiem”.

${ }^{73}$ Por. tamże 22, 28 i 29, CSEL 54, 188, Czuj I 145: „Nie mają one innej troski, jeno brzuch i to, najbliższe brzucha (nulla illis nisi ventris cura est et quae ventri proxima)”.

${ }^{74}$ Por. tamże 22, 28-29; 50, 5; 54, 13; 147.

${ }^{75}$ Por. tamże 147, 4, CSEL 56, 319, Czuj III 438: „Nie wyliczam [...], żeś podobno znieważył wiele dziewic, że znieważone przez ciebie szlacheckie małżeństwa zostały publicznie ukarane mieczem”; tamże 147, 11, CSEL 56, 327-328, Czuj III 444-445: „Wreszcie płomień bezwstydu sprawił, że wpadłeś między miecze barbarzyńcy i barbarzyńskiego małżonka [...]. Nie obawiałeś się popełniać cudzołóstwa w owym domu [...], iż w czasie nieobecności męża masz żonę, nie cudzołożnicę".

${ }^{76}$ Por. tamże 147, 4, CSEL 56, 319, Czuj III 438: „[...] jak wstrętny rozpustnik biegałeś po domach publicznych. Wielkie wprawdzie i ciężkie to są grzechy".

${ }^{77}$ Por. tamże 147, 4-7.

${ }^{78}$ Por. tamże 147, 6, CSEL 56, 321, Czuj III 439: „Nie mówię nic więcej, żeś się rzucił do pocałunków, żeś ją obejmował. Wszystkiego wprawdzie można się po tobie spodziewać, ale poszanowanie stajenki i tego miejsca nie pozwalają mi przypuszczać więcej nad to, żeś tylko chęcią i myślą upadł".

${ }^{79}$ Por. tamże 147, 6, CSEL 56, 321, Czuj III 439-440: „Jako jakąś rękojmię przyszłego małżeń- 
możliwość uratowania w nim choć resztek człowieczeństwa ${ }^{80}$. Chciałoby się powiedzieć, że tego rodzaju wykroczenia i dewiacje w mentalności Hieronima są niczym innym, jak działaniem samego diabła, który moc swego oddziaływania pokłada $\mathrm{w}$ przyrodzeniu kobiet i mężczyzn ${ }^{81}$, a pierwsze ich przejawy dostrzega już w herezji nikolaitów i ofitów ${ }^{82}$.

Reasumując powyższe spostrzeżenia i refleksje na temat wykroczeń i dewiacji popełnianych na tle seksualnym, jako skutku obecności tajemnicy nieprawości w świecie, zebrane w oparciu o listy św. Hieronima, dowodzą, że człowiek - chrześcijanin, a w tym także osoba duchowna, przez brak roztropności, a także i przez własną głupotę, może stać się przeciwieństwem znaku obecności Boga w świecie ${ }^{83}$, obarczając się w ten sposób - zgodnie z myślą Strydończyka - osobistą winą za śmierć Chrystusa, a tym samym przede wszystkim winą za zaprzepaszczenie własnego człowieczeństwa. ${ }^{84}$ Taki człowiek, chociaż stworzony przez Boga ex nihilo z miłości do niego, zmierza poprzez tego rodzaju postępowanie w sposób samowolny do własnego samounicestwienia, odrzucając tym samym prawdę o Krzyżu, jako znaku zwycięstwa, na którym objawiła się w pełni miłość Boga w Chrystusie, prawdziwym Bogu i prawdziwym człowieku ${ }^{85}$.

stwa bierzesz w owej czcigodnej grocie włosy, chusty i pasek nieszczęsnej [...] śmiesz przyjmować włosy [...], aby spały z tobą nocami?”.

${ }^{80}$ Por. tamże 147, 9.

${ }^{81}$ Por. tamże 22, 11, CSEL 54, 159: „Omnis igitur adversus viros diaboli virtus in lumbis est, omnis in umbilico contra feminas fortitudo".

${ }^{82}$ Por. tamże 147, 4; zob. H. Masson, Słownik herezji w Kościele katolickim, tłum. B. Sęk, Katowice 1993, 227 i 230-231.

${ }^{83}$ Por. Hieronymus, Epistulae 49, 15; 6, 2, CSEL 54, 25: „Et licet me sinistro Ibera excetra ore dilanit" (mowa o Lupicynie, kapłanie sprzedajnym i szkodliwym, który prawdopodobnie był uczestnikiem upadku i winy siostry Hieronima, zob. Epistulae 22, 28).

${ }^{84}$ Por. tamże 147, 10, CSEL 56, 326, Czuj III 443: „Już wyżej powiedziałem, że ani ojciec za syna, ani syn za ojca nie bywa karany. Bowiem «dusza, która grzeszy, ta umrze»».

${ }^{85}$ Por. tamże 22, 17; 79, 9, CSEL 55, 98-99, Czuj II 221-222: „Z tego jasno wynika [...], że serce człowieka od młodości jest skłonne do złego i że między uczynkami ciała i ducha, [...], dusza waha się niezdecydowanie pragnąc raz jednych, raz drugich. [...]. Odnieśmy do innych zaburzeń to, co zostało powiedziane o jednym. [...]. W ten sposób wszelkie ciało pożąda właśnie tego, co jest cielesne i pewnymi ponętami pociąga duszę do zgubnych przyjemności, lecz naszą powinnością jest hamować gorącą namiętność większą miłością Chrystusa”; 147, 6, CSEL 56, 322, Czuj III 440: „,...] gdzie przez włożenie zasłony Chrystusowej została poświęcona, po tajemnicach krzyża". 
THE PROBLEM OF SEXUAL OFFENCES, AS A RESULT OF THE MYSTERY OF INIQUITY PRESENT IN THE WORLD, IN THE LIGHT OF ST. JEROME'S LETTERS

\section{(Summary)}

The author of the article: „The problem of sexual offences, as a result of the mystery of iniquity present in the world, in the light of St. Jerome's letters", shows paradox of human existence, in which men, as a real being, continually escapes into the world of dreams and utopia; as a social being, adores in himself anarchistic behaviors; moral and religious values are precious for him, however by the whole of his existence opposes them; he speaks about the ideals of truth, justice and love, but in practice uses false in the wide sense of this word, without difference of time in which he lives and systems under which he exists. 